\title{
What Motivates a Developer to Sell before Completion?
}

\author{
L. $\mathrm{Li}^{1}$ (D) K. W. Chau ${ }^{2}$
}

Published online: 5 June 2018

(C) The Author(s) 2018

\begin{abstract}
Presale, or selling before completion, is a very common phenomenon in the housing market. However, not all developers presell their units and the proportion of units presold varies over time and across projects. This study examines the factors that affect developers' decisions to presell their units. Based on housing transaction records on over 1000 projects in Hong Kong, we found that presale has been used as a tool to hedge against future price fluctuations. Developers' decisions to presell also depend on its effectiveness as a hedging tool, which increases with the size of the development portfolio held by a developer. When the flexibility of a presale is constrained by regulations, its effectiveness declines, thus giving a developer less incentive to presell. Contrary to industry wisdom, presale is not an important source of financing, at least for listed developers in Hong Kong.
\end{abstract}

Keywords Presale $\cdot$ Hedge real estate risk $\cdot$ Regulation $\cdot$ Housing

JEL Classification $\mathrm{D} 02 \cdot \mathrm{D} 22 \cdot \mathrm{D} 81 \cdot \mathrm{R} 31$

\section{Introduction}

We investigate why developers presell and why presales and spot sales (or sales after completion) coexist in the marketplace. Presale refers to a developer selling a residential unit in a development prior to its completion or even before its construction. A

L. Li

11496@cam.ac.uk

$\triangle$ K. W. Chau

hrrbckw@hku.hk

1 Department of Land Economy, The University of Cambridge, Silver Street 19, Cambridge CB3 9EP, UK

2 Ronald Coase Centre for Property Rights Research, HKUrbanLab, The University of Hong Kong, Pokfulam Road, Hong Kong, China 
developer and homebuyer agree on the price of a presold unit at the date of a presale, but the unit can only be transferred to the buyer at its date of completion. Presale contracts offer some potential benefits to developers and homebuyers. For developers, they can mitigate the risk associated with future price uncertainties by securing a favorable transaction price at an early stage. In some jurisdictions, the revenue from presales can be used to finance their developments. For homebuyers, presale payment arrangements (usually low deposits to secure future ownership of housing units) can overcome initial payment constraints. Short-term speculators may also make use of the presale payment arrangements to create highly geared options or forward contracts with expectations of reselling the properties for profit before their completions. Presale transactions also serve the function of price discovery in the spot market. Presale prices and trading volumes have been used to forecast future housing prices.

As a result of these advantages to both buyers and sellers, presales have been a popular tool for selling properties in recent decades. Hong Kong and Taiwan's presale systems go back to the 1950s and 1960s, respectively. Later, Shenzhen adopted this system and launched its first presold project in 1980, but not until 1994 was it formally adopted across China (Deng and Liu 2009). It is also the dominant property disposal strategy by developers in Singapore, as Ong (1997, 1999) and Hwang and Quigley (2010) have shown. Nevertheless, the functions of the presale system are not always appreciated, at least by governments. Hong Kong's presale market has long been criticized as encouraging speculation because the high leverage and no immediate transaction tax (stamp duty) for a presale transaction before $1994^{1}$ attracted shortterm speculators to this market (Chang and Ward 1993). The Hong Kong Government introduced anti-speculative measures in $1994^{2}$ (and partly relaxed them in 1998), which aimed to prevent such activities and protect the interests of real homebuyers. However, without a clear understanding of the functions of this system, any well-intended government intervention often has a negative impact on the market. For example, a study by Wong et al. (2006) suggested that anti-speculative measures increased the volatility of housing prices.

Despite decades of presales in many housing markets, it has not received much academic attention. A literature search showed that the most frequently addressed research issues related to presale pricing and price discovery (Chang and Ward 1993; Wang et al. 2000; Chau et al. 2003; Wong et al. 2007; Fan et al. 2012). But if a presale is an institutional arrangement that benefits both buyers and sellers, it should supersede other property disposal arrangements including sales after completion (spot sales). Why don't all developers presell their units? Why do both presales and spot sales co-exist? In reality, the developer's decision on how to dispose its properties is not a dichromic decision between the presale and spot sale of the development, but one that determines the proportion of units that would be presold. This raises another issue: why do the proportion of units presold vary over time and across projects? Only a few studies addressed this and related issues - theoretically under institution-free assumptions (Lai

\footnotetext{
${ }^{1}$ Before 1994, a residential property buyer in Hong Kong did not have to pay a stamp duty after signing a purchase agreement until the title was formally transferred. Both parties agreed on the time between the signing of the purchase agreement and when the title was transferred, which can range from one to three months (sometimes longer). This loophole gave short term speculators the chance to sell their properties before the title transfer and, thus, avoid paying any stamp duty.

${ }^{2}$ Details are given in the following section.
} 
et al. 2004; Chan et al. 2008; Edelstein et al. 2012). The problem becomes even more complicated if there are institutional constraints on developers' flexibility to presell.

In reality, institutions and regulatory constraints matter in the property market because they could severely limit a developer's flexibility to presell, which would deviate significantly from the institutional free assumption adopted in previous theoretical analyses (Yao and Pretorius 2014). Theoretical analysis based on institutional free assumptions often deviate too much from reality, which limits its usefulness in explaining real life phenomena. This may partly explain why there have been very few applications of these theories to explain the observations in the presale market.

We aim to understand the housing presale market while recognizing the importance of institutional constraints. There are, accordingly, two objectives. The first is to examine what motivates a developer to presell by identifying the set of factors that determine its presale decision, as shown by the proportion of units presold in a development. The second is to investigate how institutional and regulatory constraints affect developers' presale decisions. The empirical results of this paper should shed light on the functions of the presale system and explain why both presales and spot sales co-exist in the housing market.

The abundance of presales data in Hong Kong (see Table 1), together with its changing institutions and regulations governing the presale system, allow us to fulfil the aforementioned objectives. Hong Kong has a very active presale market for a number of widely-believed reasons. First, capital-constrained homebuyers may be tempted to enter into presale agreements that allow them to secure ownership of properties by paying modest down payments, especially when property prices spike. Higher leverage and lower transaction costs also make presales an attractive short-term investment vehicle. Second, developers could utilize the presale method to generate funds to finance their developments and hedge against risk in a volatile market.

Table 1 Number of presales to the total number of sales on the first-hand property market of Hong Kong, 1993-2014

\begin{tabular}{llllllll}
\hline Year & $\begin{array}{l}\text { No. of 1st } \\
\text { hand sales }\end{array}$ & $\begin{array}{l}\text { No. of 1st } \\
\text { hand presales }\end{array}$ & $\begin{array}{l}\text { \% of 1st } \\
\text { hand presales }\end{array}$ & Year & $\begin{array}{l}\text { No. of 1st } \\
\text { hand sales }\end{array}$ & $\begin{array}{l}\text { No. of 1st } \\
\text { hand presales }\end{array}$ & $\begin{array}{l}\text { \% of 1st } \\
\text { hand presales }\end{array}$ \\
\hline 1993 & 23,432 & 17,801 & $75.97 \%$ & 2004 & 23,955 & 11,986 & $50.04 \%$ \\
1994 & 14,171 & 8252 & $58.23 \%$ & 2005 & 14,276 & 8659 & $60.65 \%$ \\
1995 & 17,499 & 7211 & $41.21 \%$ & 2006 & 12,083 & 7054 & $58.38 \%$ \\
1996 & 19,587 & 7873 & $40.20 \%$ & 2007 & 16,995 & 4999 & $29.41 \%$ \\
1997 & 20,673 & 14,660 & $70.91 \%$ & 2008 & 7923 & 5622 & $70.96 \%$ \\
1998 & 28,720 & 22,109 & $76.98 \%$ & 2009 & 13,660 & 9418 & $68.95 \%$ \\
1999 & 19,352 & 13,148 & $67.94 \%$ & 2010 & 10,600 & 7909 & $74.61 \%$ \\
2000 & 16,689 & 10,591 & $63.46 \%$ & 2011 & 10,040 & 5853 & $58.30 \%$ \\
2001 & 22,042 & 12,766 & $57.92 \%$ & 2012 & 11,221 & 9237 & $82.32 \%$ \\
2002 & 24,747 & 12,684 & $51.25 \%$ & 2013 & 9580 & 7967 & $83.16 \%$ \\
2003 & 27,831 & 14,381 & $51.67 \%$ & 2014 & 14,533 & 11,010 & $75.76 \%$ \\
\hline
\end{tabular}

Source: raw data from the Economic and Property Research Centre (EPRC) 
Although Hong Kong is known as a lassie-faire economy, its presale market has often been a target for government intervention, especially during boom times. Preselling properties in Hong Kong is regulated under the Consent Scheme (newly-granted land lease) or Non-consent Scheme (redevelopment projects). Under the former, there are regulatory constraints on the timing of presales, whereas under the latter, developers are free to presell at any time, which gives them a lot more flexibility. The government can change the regulatory constraints under the Consent Scheme, but not under the Non-consent Scheme. The difference in flexibility between the two schemes is even larger during periods when the government imposes further restrictions on preselling properties (under the Consent Scheme) to attempt to curb speculation. Such changes in regulatory constraints allow us to empirically examine how changes in presale flexibility affect developers' presale decisions.

The remainder of this paper will proceed as follows. We begin by describing the Hong Kong presale system in "Hong Kong's Presale System" section. "Literature Review" section provides a brief review of the studies on property presales. We developed a set of testable hypotheses in "Hypotheses" section. "Empirical Tests and Data" section describes the empirical models and data for testing the hypotheses, the results of which are presented in "Results" section. The last section concludes the paper.

\section{Hong Kong's Presale System}

Transactions of uncompleted residential properties in Hong Kong were first recorded in 1954 at a housing estate of over a hundred blocks of three-floor buildings (Leung et al. 2007a). After decades of development, presales have become a popular means of property disposal in the primary market. Through presales, developers can reduce their financing and inventory costs, discover the market value of properties, and hedge against project pipeline risk and risk associated with volatile market conditions. Homebuyers also like presales because they allow them to place much lower down payments to buy property, as well as present a lower exit barrier due to the absence of provisions banning the resale of uncompleted units. Above all, this lasting dominance mainly resulted from a sound institutional guarantee for both builders and buyers and evolved over the decades.

To reduce the risk of default by developers, the government introduced two critical rules. First, a developer had to show proof of its financial ability to complete a development such as a guarantee from a bank or associated financial community. Before the introduction of this rule during the early 1960s, a number of developers folded before they completed their projects due to cash flow problems. The Consent Scheme was then introduced to regulate presales. Consent to presell under this Scheme would be given to a developer only if the Lands Department is satisfied with, among other things, the developer's financial arrangements and the stage of development reached in its project. ${ }^{3}$ The allowed presale period, a maximum presale time frame prior to a building's completion, is limited and recognized as a measure for preventing

\footnotetext{
${ }^{3}$ Currently, consent can be given if the foundation of a development has been laid and approval to commence construction on the superstructure has been given.
} 
speculative dealings on the buyers' side for undeveloped land. Second, unlike China, where buyers' presale funds are transferred to developers all at once (Deng and Liu 2009), the funds paid by homebuyers during the presale stage in Hong Kong are kept by solicitors and released to developers by development progress. Still, a considerable amount of financing can be saved if interest rates are high, but the interests of presale buyers are better protected. Both the presale consent and payment release by progress are taken as assurances for buyers to urge developers to complete their projects, as specified in their contracts.

The Consent Scheme only applies to buildings that are erected on land governed by a building covenant. Buildings not erected on land granted by the Government for development purposes are governed by the Non-consent Scheme. An example under this Scheme is a structure built on a plot of land obtained by a developer after the original building was demolished. Theoretically, no regulation is imposed on the presale system under this Non-consent Scheme, although the law requires that buyers be protected as if the Consent Scheme applied. Developers can freely choose the presale timing without the need to apply for consent from the Lands Department. Undoubtedly, developers in Non-consent Scheme projects are in a better position to exploit the presale benefits. The earlier they can presell their uncompleted units, the higher possible gains they can realize from this alternative source of development finance, as well as the greater flexibility they would have to cope with future price uncertainties.

Other institutional means also protect resale buyers. For example, to deter intentional delays in completion, homebuyers are allowed to rescind their agreements or receive interest lost on their payments and other necessary expenses if no extension of the construction was approved (Leung et al. 2007b). Besides, a one-year liability warranty is issued to deter building defects so that developers could remedy any defect in a completed property for one year after its completion. These protective measures perform quite well, as evidenced by the active presale market. This activeness, on the contrary, has been criticized for being responsible for the inflated property prices of the early 1990s, since presales are deemed as conducive to speculative activities.

Thereafter, presale rules were changed in mid-1994, when the government adopted anti-speculative measures that aimed to rein in the spiraling property price increases and protect the interests of potential homebuyers who intended to be end users (Lands Department, Hong Kong 1999). Four policies that had important bearings on the functioning of the presale system were modified. First, the resale of uncompleted units bought through presale arrangements were prohibited before the Certificate of Compliance $^{4}$ or consent-to-assign was issued. Second, the permitted presale period was further shortened from 24 months to no more than nine months prior to a project's anticipated completion date. Third, the proportion of uncompleted flats for internal sales was reduced from 50 to $10 \%$, which forces developers to bear the risk of marketing completed units directly to the public. Finally, the initial deposit required upon signing a preliminary Agreement of Sale and Purchase was increased from 5 to $10 \%$ of the purchase price, while half of the deposit would be forfeited if the buyer failed to sign the Agreement. These changes were a significant disincentive to

\footnotetext{
${ }^{4}$ The Certificate of Compliance is issued when a development is completed and complies with all the positive obligations stipulated in its lease.
} 
prospective homebuyers who saw property as a lucrative, short-term investment, as the lower barriers to entry and exit under the presale system were raised. Similar for developers, the effectiveness of the presales system as an alternative source of project financing and risk-hedging were substantially weakened due to the presale timing restrictions.

These restrictions were partly relaxed when the property market collapsed in late 1997. Between May and September 1998, the Lands Department announced a relaxation of the permitted period of presale from 9 months to no more than 15 months, reduced the initial deposit from 10 to $5 \%$, suspended the sub-sales restriction on uncompleted flats, and increased the portion of flats allocated to private internal sales by developers from 10 to $20 \%$. Obviously, to reduce the opportunities for speculation between sale and assignment, the flexibility of the presale system was significantly reduced with the presale period being shortened to 24 months before the completion date in the Consent Scheme and shortened again to no more than nine months during the intervention period. But it is worth noting that these anti-speculative measures only applied to projects under the Consent Scheme, which were further restrained in their flexibility to be presold compared to Non-consent Scheme projects during the intervention period.

The default risk of homebuyers is also minimized. Under Hong Kong's common law regime, a failure to honor the terms in the Agreement of Sale and Purchase constitutes a breach of contract. The considerable default costs are intended to compel buyers to comply with the terms of their presale contracts at the time of delivery. ${ }^{5}$ Hence, a presale contract can be recognized as a forward contract and once it is signed the buyer is implicitly obliged to purchase the property when it is completed. There are a few exceptions, however. In Hong Kong, a small percentage of buyers are companies often shell corporations without real assets. These institutional buyers are more likely to default on their outstanding balances in case the market unexpectedly falls. This is because the right of recourse in Hong Kong only applies to the company instead of the individuals who represent it. Developers certainly bear a stronger default risk when trading with company buyers. To mitigate such increased risk, they tend to charge company buyers more. Under this circumstance, a presale contract can be treated as a real option with the right to default, but at a higher price.

To conclude this section, a well-developed presale system exists in Hong Kong to protect the interests of buyers and developers. Characterized apart from other markets, the special institutional arrangements between the Consent Scheme and Non-consent Scheme and the changes in Hong Kong's presale rules provide an excellent empirical arena for examining the critical factors that motivate developers to presell.

\section{Literature Review}

Only a sparse set of theoretical foundations was established to account for the presale contracts. Assuming risk-neutral market participants in the model by Chan et al. (2008), both buyers and developers would be indifferent towards

\footnotetext{
${ }_{5}^{5}$ buyer can default only when there are clear stipulations that allow for it in the presale contract s/he signs with a developer. 
presale and spot sale methods in an efficient market without financial constraints. However, when financing may not be available to developers at a reasonable cost, the presale system is superior for selling until a project's completion for both developers and buyers. It can make prepayments to mitigate developers' financing constraints on the one hand and allow homebuyers to enjoy lower sales prices on the other. Deng and Liu (2009) estimated a financial benefit of about 250 basis points for condominiums using presale contracts in Beijing. Several years later, Edelstein et al. (2012) studied risk-averse buyers with heterogeneous beliefs about future real estate price distributions and reached a similar conclusion using an equilibrium model. Besides the financing cost savings, they found the presale benefit a function of developers' belief about future housing prices and real estate risk, buyers' heterogeneity, and the default probability of buyers and developers. It is noteworthy that they incorporated the default option of buyers as one of the factors that could affect developers' presale benefits, which makes the use of the real option and forward contract framework comparable when modelling a presale contract.

Edelstein et al. (2012) emphasized the function of a presale in mitigating real estate valuation risk for buyers but a developer requires a presale premium as compensation for insuring against future price risk. Admitting that presales were mainly for risksharing purposes, Lai et al. (2004) suggested that the benefit was better-suited for the developer's side in a real-option framework. They concluded that developers should optimally presell whenever they are allowed so that they could have a steadier revenue source by agreeing to prices for their products at the start of their production processes. Presales provide insurance for developers against future price uncertainties, while homebuyers could expect discounts for buying units before they are completed (Deng and Liu 2009). Chang and Ward (1993) insisted that price discounts are risk premiums for homebuyers who have to assume the risks that developers want to hedge away. Nevertheless, they observed presale premiums for developers in Taipei from 1988 to 1990 after taking into account carrying costs such as depreciation. But it seems problematic to compare the presale prices to the average prices of all existing houses, which depreciate a lot.

In summary, we found that at least two presale benefits for developers lacked empirical evidence. First, developers produce dwelling units with sales price uncertainties and can utilize the presale system as a future hedging strategy. This riskhedging function also applies to buyers. Second, developers can access additional financing. However, these presale benefits are presumably appreciated equally by all developers, which obviously does not make sense. For example, demand for this alternative form of financing among developers should vary according to their financial situations. A financially constrained developer would probably appreciate presales more. Only Lai et al. (2004) provided an exception to this rule when they claimed the importance of developers' reputations depended on their initiative in selecting presale contracts with high down payments. Moreover, the presale advantage should be subjected to the institutions of the underlying market (Wang and Zhou 2006), which have usually been overlooked in the literature. The choice to presell can, to a large extent, be limited by the underlying legal regime, notably the conditions under which a presale is allowed. If a presale is only allowed when the market remains flat, its risk-sharing function will play no role. This requires 
researchers to consider the institutional factors related to the presale system when examining its practical function.

As a result, investigations by previous researchers of the presale system are insufficient. The theoretical results varied in their specific assumptions, whilst only a few empirical studies explained the existence of the presale system. A comprehensive understanding of the function of the presale system is important, in particular when the presale market is frequently criticized as being conducive to speculative activities. Therefore, it would be fruitful to test why an idiosyncratic developer, often the main initiator of a presale system, presells subjected to various institutional limitations. The empirical results of this study should provide insights into how to improve the theoretical foundations of presales and recommend to the Government when it should cool down the property market by suppressing the presale market.

\section{Hypotheses}

We started with the presale model by Chan et al. (2008). Developers and buyers are indifferent to presales and spot sales under the following four conditions: 1) no financial constraints for developers, 2) risk-neutral developers and homebuyers, 3) no institutional constraints, and 4) homogeneous developers and buyers. However, these assumptions do not apply to most cases. The main proposition of this study is that in reality, these conditions are rarely satisfied and, thus, developers' decisions to presell tend to be affected by how much real-life situations deviate from these conditions. Following this proposition, we proposed seven testable hypotheses as described below.

\section{Financial Constraint}

Developing a housing project is a lengthy and costly exercise. One benefit of a presale is that it helps developers lower their financial burdens caused by higher production costs in lengthier development projects. Contrary to the assumption of no financial constraint, developers always have to finance their projects at considerable costs, particularly in tight capital markets. Presales can be used to raise capital, since down payments from homebuyers can either be directly used to finance housing construction or as collateral to lower the cost of borrowing. The potential benefits of presales are, thus, higher when the cost of capital is high. This leads to our first hypothesis:

\section{Hypothesis 1(H1):}

A developer has a stronger incentive to presell when real interest rates are high, ceteris paribus.

\section{Real Estate Price Volatility}

Usually, it takes a developer at least two years to complete a residential development. This means it has to start construction only when there is projected 
future demand or else the developer would have to bear the consequences of a future decline in demand. If housing prices fall due to an unexpected decline in demand, a financially-constrained developer could face very serious consequences. Given the price volatility risk, developers that face financial constraints should be more risk-averse (Lai et al. 2004). In reality, developers are financially constrained because they do not have an unlimited supply of capital. Therefore, risk-averse developers are more likely to lower the risk of future price fluctuations by preselling units at an early stage. This means that it is unrealistic to assume that all developers are risk-neutral at all times. They are more likely to be risk-averse when prices are highly volatile. By locking into prices with homebuyers, developers can reduce their exposure to housing price fluctuations in the future. An incentive to presell increases when price volatility is expected to be high. This leads to our second hypothesis:

\section{Hypothesis 2 (H2):}

A developer has a stronger incentive to presell when the expected future price volatility increases, ceteris paribus.

\section{Hedging Effectiveness}

The best time for developers to hedge against future housing price fluctuations is right after it acquires land. This is especially important in Hong Kong, where land prices are the biggest cost in housing production (Wong et al. 2012). If a developer acquires a plot of land $^{6}$ at a high price during a housing boom, a potentially profitable development may become unprofitable if housing prices go down after its completion. A longer time span between the land acquisition and sale of a housing unit implies higher risk, which can be eliminated if the developer can presell at the same time as it acquires the land. However, a presale cannot occur without approved plans, since buyers need to know what they are buying. There are also regulatory restrictions on the timing of presales so that risk still exists in housing price fluctuations between land acquisition and presale. A developer can try to hedge this risk by spreading it out across projects: presell units in Project A when land is acquired for Project B. But this strategy may not work for two reasons. First, the price trends of the two projects may vary. Second, there may not be any suitable project available for presale after land is acquired. The first reason is usually not a problem in Hong Kong, since it is a small place where prices in different locations tend to fluctuate together. The second problem is more serious for smaller developers with smaller development portfolios. The effectiveness of cross-project hedging is a function of the size of a developer's development portfolio. Therefore, compared to smaller developers, larger developers have more incentive to use presales as a

\footnotetext{
${ }^{6}$ In Hong Kong, a developer can acquire new developable land by: (a) directly purchasing it from the government through auction or tender and (b) converting land it already owns for residential use by paying a land premium that reflects the increase in land value due to the change of use (Yao and Pretorius 2014). In either case, the developer pays the prevailing market price of the land when it acquires it.
} 
tool for hedging against housing price fluctuations. This leads to the following hypothesis:

\section{Hypothesis 3 (H3):}

A developer with a larger housing development portfolio has a stronger incentive to presell, ceteris paribus.

\section{Project-Specific Risk}

Each project has its specific risk. In theory, unsystematic risk can be eliminated by diversification. In reality, the size of a housing development project could be very large compared to the total equity of a developer. Capital constraints limit the ability of smaller developers to diversify away project-specific risks effectively, especially for large projects. Project-specific risk is more serious when the size of the project relative to the equity of the developer is large. To lower this risk, a developer would have an incentive to presell as quickly as possible. Without a presale system, developers cannot hedge against project-specific risks when they develop projects that are large relative to their equity (Lai et al. 2004). With one, developers can sell all or significant portions of their projects earlier and, thus, reduce their exposure to project-specific risk. This leads to our fourth hypothesis:

\section{Hypothesis 4 (H4):}

A developer has a stronger incentive to presell when the size of its development relative to its equity is high, ceteris paribus.

\section{Presale Flexibility}

The presale system is often assumed to be free from regulatory constraints in terms of presale parameters, but this is usually untrue. Under this assumption, Lai et al. (2004), for example, claimed that a presale is superior to a spot sale due to its flexibility in timing and quantity. However, such superiority cannot be achieved if the developer's freedom to choose presell parameters is constrained by regulation. If, for example, there are constraints on when and how much to presell, the benefits of a presale cannot be fully realized. We use the term, "presale flexibility," to mean the degree to which a developer can freely choose its presale parameters. High presale flexibility means little or no regulatory restriction on a developer's choice of presale parameters. Presale flexibility may vary over time or across projects due to changes in regulations. The benefit of a presale is lower when there are more restrictions on it. This leads to the fifth hypothesis:

\section{Hypothesis 5 (H5):}

A developer's incentive to presell increases with increased presale flexibility, ceteris paribus. 
When presale flexibility is constrained, its usefulness in hedging against price volatility declines. As a result, there is less incentive for developers to use presale as a tool to hedge against price volatility. This leads to the following hypothesis:

\section{Hypothesis 6 (H6):}

A developer's presale decision is less sensitive to increases in excepted price volatility if the restriction on presales increases, ceteris paribus.

After relaxing the homogenous homebuyer assumption, Edelstein et al. (2012) observed that a higher level of buyer heterogeneity was associated with both a higher presale price and larger presale transaction volume. Developers can charge higher prices for presale contracts by taking advantage of the divergent expectations of consumers due to information asymmetry.

At the presale stage, consumers have to rely on sales brochures and promotional activities. They do not have information on the quality of the units they want to buy. When a presale contract is signed, a developer may have the incentive to lower product quality to a level that does not constitute a breach of contract. This is a typical moral hazard problem that was first identified by Ong (1997) in the presale market. Later on, Chau et al. (2007) provided evidence that developers can use their reputations to vouch for the quality of their products. However, relying on reputation only works for a few large developers and can only attract repeat business. Chau and Choy (2011) found that developers can exploit their information advantage over prospective buyers through pricing strategies in the presale market. There are information asymmetries in different aspects of the presale market, but developers are more likely to exploit their advantage in the quality department, which is difficult for the average buyer to measure or enforce. One such quality is communal facilities, which include clubhouses, swimming pools, sports facilities, etc. Unlike the quality of the building structure, which a developer has to guarantee for one year, there is no clear regulation that requires a developer to provide communal facilities of a certain standard. Because of their information advantage in this aspect over most buyers, developers are more willing to spend resources to promote uncompleted units in larger developments with more communal facilities, which leads to our last hypothesis:

\section{Hypothesis 7 (H7):}

A developer has a stronger incentive to presell when information asymmetry on the quality of a communal facility is more lopsided, ceteris paribus.

\section{Empirical Tests and Data}

A developer's presale decision is measured by the number of units presold as a percentage of all units in its development project (PRE). PRE equals 0 for projects without presales. A higher $P R E$ value means a stronger motivation to presell. We used the percentage of units presold, rather than the percentage of 
units listed for presale, since developers may list some units for presale with no real intention to sell at the prevailing market prices. These units are listed at above market prices and may not be sold before completion. Therefore, the units that are actually presold reflect the developer's true intention to sell, which is more accurate than the units listed for presale.

The empirical tests require data on the date $\left(T_{D}\right)$ when a developer decides to presell $\left(\mathrm{T}_{\mathrm{DP}}\right)$ or conduct a spot sale $\left(\mathrm{T}_{\mathrm{DS}}\right)$. We assume that developers start selling through presales. Therefore, $\mathrm{T}_{\mathrm{DP}}$ is taken as the transaction date of the first presold unit. For projects without presale, $\mathrm{T}_{\mathrm{DS}}$ is taken as nine months ${ }^{7}$ before the completion (occupation permit) date.

The list of variables and their descriptions are listed in Table 2.

The following equation was estimated with the entire sample (all projects developed between 1995 and 2015) as the baseline model (Model 1):

$$
\begin{aligned}
P R E= & \beta_{0}+\beta_{1} R I R+\beta_{2} V O L+\beta_{3} I 94-98+\beta_{4} M S H+\beta_{5} C O N S+\beta_{6} S I Z E \\
& +\beta_{7} L V A+\beta_{8} A S F A+\beta_{9} B D P+\beta_{10} A D P+\varepsilon
\end{aligned}
$$

Equation (1) was re-estimated with two sub-samples: projects by listed (Model 2) and unlisted (Model 3) developers. Two more developer characteristic variables, DER and PROR, and one more development characteristic variable, $S C O M,{ }^{8}$ were added to Eq. (1) as independent variables, as shown in Eq. (2) (Model 4). Developer fixed effects were also included in Model 4. These variables were not available for Model 3. The listed-developer sample was further divided into subsamples with Consent Scheme projects (Model 5) and Non-consent Scheme projects (Model 6). The latter were redevelopment projects with no-restriction on the timing of their presales.

$$
\begin{aligned}
P R E= & \beta_{0}+\beta_{1} R I R+\beta_{2} V O L+\beta_{3} I 94 \_98+\beta_{4} M S H+\beta_{5} C O N S+\beta_{6} S I Z E \\
& +\beta_{7} S C O M+\beta_{8} A S F A+\beta_{9} L V A+\beta_{10} B D P+\beta_{11} A D P+\beta_{12} D E R \\
& +\beta_{13} P R O R+\varepsilon
\end{aligned}
$$

A developer's finance cost is determined by its debt-to-equity ratio $(D E R)$ and the real market interest rate $(R I R)$. RIR is measured as the 12-month Hong Kong Interbank Offered rate minus the inflation rate (according to the Hong Kong Composite Consumer Price Index) one month before $\mathrm{T}_{\mathrm{D}}$. $\mathrm{H} 1$ implied that RIR's coefficient was positive and significant. Furthermore, compared to unlisted developers, listed developers can raise capital on the market. Therefore, they are less likely to be affected by higher interest rates. Thus, $\mathrm{H} 1$ also implied that RIR's coefficient was more significant and larger for unlisted companies (Model 3) than those for listed ones (Model 4). We also expect the coefficient of $D E R$ to be positive and significant in Model 4.

In addition, we assume that expectations of future price volatility are based on past experiences and changes in policies that are known to have an impact on housing price

\footnotetext{
${ }^{7}$ This is the maximum allowed presale period for Consent Scheme projects and the average presale period for all projects in our sample.

${ }^{8}$ It is due to data limitations.
} 
Table 2 Variable descriptions

\begin{tabular}{|c|c|}
\hline Variables & Descriptions \\
\hline \multicolumn{2}{|c|}{ Dependent variable } \\
\hline PRE & $\begin{array}{l}\text { The presale percentage in each project or phase if the project is developed in multiple } \\
\text { phases on the } 1 \text { st hand market }\end{array}$ \\
\hline \multicolumn{2}{|c|}{ Independent variables } \\
\hline \multicolumn{2}{|c|}{ \# Market characteristics } \\
\hline RIR & $\begin{array}{l}\text { The 12-month Hong Kong Interbank Offered Rate minus the inflation rate } \\
\text { at }\left(\mathrm{T}_{\mathrm{D}}-1 \text { month) }\right.\end{array}$ \\
\hline VOL & $\begin{array}{l}\text { The standard deviation of the monthly property returns between }\left(T_{D}-2 \text { years }\right) \\
\text { and } T_{D} \text { using the RVD's price index }\end{array}$ \\
\hline BDP & The ratio of the price index at $T_{D}$ to that at $\left(T_{D}-2\right.$ years $)$ \\
\hline $\mathrm{ADP}$ & The ratio of the price index at $T_{O P}$ to that at $T_{D}$ \\
\hline \multicolumn{2}{|c|}{ \#Developer characteristics } \\
\hline DER & The ratio of the book value of debt to the market value of equity at $T_{D}$ \\
\hline $\mathrm{MSH}$ & The supply of housing units as a $\%$ of total supply in the next two years \\
\hline PROR & $\begin{array}{l}\text { The ratio of the development's size to the market capitalization of the listed } \\
\text { developer at ( } \mathrm{T}_{\mathrm{D}^{-}}-1 \text { quarter) }\end{array}$ \\
\hline \multicolumn{2}{|c|}{ \# Property characteristics } \\
\hline LIS & 1 if the estate was developed by a listed developer; 0 if otherwise \\
\hline UNLIS & 1 if the estate was developed by an unlisted developer; 0 if otherwise \\
\hline SIZE & $\begin{array}{l}\text { Total number of units in the project or phase if the project was developed in } \\
\text { multiple phases }\end{array}$ \\
\hline $\mathrm{RCOM}$ & The ratio of the communal area to the gross floor area within the development \\
\hline LVA & $\begin{array}{l}\text { The average deflated unit sale price by district derived from the coefficients of the } \\
\text { districts in a hedonic regression }\end{array}$ \\
\hline ASFA & The average saleable floor area for flats in each development \\
\hline \multicolumn{2}{|l|}{ \# Policy } \\
\hline I94_98 & 1 if the estate began sales between 1994 and 1998; 0 if otherwise \\
\hline NCONS & 1 if the estate is under the Non-consent Scheme; 0 if otherwise \\
\hline CONS & 1 if the estate is under the Consent Scheme; 0 if otherwise \\
\hline
\end{tabular}

volatility. The expected future price volatility $(V O L)$ is measured by the standard deviation of returns on the market-wide housing price index over a two-year period before a decision to presell (i.e., $\mathrm{T}_{\mathrm{D}}$ ). The observed historical volatility has often been taken as a good estimate of future price uncertainty (Cunningham 2006). H2 implied that VOL's coefficient was positive and significant.

Changes in policies and regulations that are known to increase price volatility will also change people's expectations of future price volatility. H2 implied that these policies/regulatory changes will motivate developers to presell more. The antispeculative measures introduced from 1994 to 1998 are examples of such regulatory changes. The price discovery function of presales was seriously impaired during the anti-speculative period of 1994-1998 due to a drastic decline in the volume of transactions and restrictions placed on the resale of presold units on the second-hand 
market. Wong et al. (2006) showed that after controlling for other possible factors, the price volatility of the spot market increased significantly during this period. Regulatory changes provided an ideal window for observing the impact of an expected increase in price volatility on developers' incentives to presell. The dummy variable, I94_98, was created to represent the expected increase in volatility due to the anti-speculative measures of 1994-1998. We expect to observe more presales during this period.

The size of a developer's development portfolio is estimated by its market share $\left(M S H^{9}\right)$, which is the supply of housing units as a percentage of total supply for the next two years. This is based on the assumption that the size of a development portfolio is the number of new units supplied to the market. H3 implied that the coefficient of MSH was positive and significant.

The size of project-specific risk in relation to the size of the developer (PROR) is measured by the ratio of the number of units in a development project to the market capitalization of the developer. We also included the number of units in a development project (SIZE) to supplement PROR. H4 implied that the coefficients of SIZE and $P R O R$ in Model 4 were positive and significant.

To test the impact of presale flexibility on developers' decisions to presell, we took advantage of two very distinctive project types (Consent Scheme and Non-consent Scheme projects), which have very different presale restrictions. Non-consent Scheme projects are redevelopment projects that restrict the timing of the presale (no government approval is needed begin preselling), whereas Consent Scheme projects are subjected to regulatory controls and developers have to satisfy a number of conditions set by the Lands Department before they can start to presell. H5 implied that the chance of a presale occurring was higher for Non-consent Scheme projects or that the coefficient of CONS was negative.

H6 implied that the coefficients of VOL and $194 \_98$ are smaller and less significant for Consent Scheme projects than for Non-consent Scheme projects due to the reduced effectiveness of presale as a tool for hedging price volatility due to the more presale restrictions on Consent Scheme projects.

We believe that the last motivation for a developer to presell is to exploit its information advantage over potential buyers when projects have not yet been completed. Although developers are liable for latent defects 12 months after purchase, defects in communal facilities are much more difficult to enforce. This leads to a serious information asymmetry problem. We determined the degree of information asymmetry by measuring the ratio of the size of the communal facilities within a development to its gross floor area (SCOM). H7 implied that the coefficient of SCOM was positive and significant.

The rest are controls that mainly focus on the demand side of the presale market. A developer's decision to presell is also affected by demand. Since there are many different financial packages a developer can provide to overcome a buyer's reluctance, buyers who would otherwise be more financially constrained would be more likely to buy presale properties. Those who buy larger units are usually more financially

\footnotetext{
${ }^{9}$ It is common practice for developers to jointly develop a project. In this case, the development size was distributed among each developer according to its stake in the development. For such developments, MSH equals that of the developer with the highest stake in the development. If each developer has an equal interest, $\mathrm{MSH}$ is calculated as a weighted average market share of these developers.
} 
capable, so we used the flats' saleable floor areas in each development ( $A S F A)$ as a proxy of buyers' financial strengths. Buyers of larger flats are more likely to be upgrading or investors who suffer less from financial constraints (Li and Chau 2017). On the other hand, smaller unit buyers are likely to be first-time buyers who are usually more financially constrained. We expect the impact of ASFA on PRE to be negative.

As proposed by Wong et al. (2012), housing quality is not as fully asymmetric, but information on land attributes is much more transparent than that on building structures. Assuming that the value of a building structure (proxied by construction cost) is about the same within Hong Kong, then the differences between housing units in different locations are mainly due to differences in land price. Higher-priced locations (with other things being equal) tend to have higher land prices and, thus, suffer less information asymmetry. Homebuyers are more likely to be attracted to projects in more expensive locations (measured by land value index $L V A^{10}$ ) and have higher PRE.

Prospective buyers are more willing to buy uncompleted units in the presale market when prices are expected to increase after purchase. Leung et al. (2007b) provided evidence of this by using Hong Kong presales data, which indicated that buyers paid a premium for uncompleted units during a boom market. However, developers would have less incentive to presell if the expected spot prices at the end of a contract period increase (Chang and Ward 1993). The impact of such increases on $P R E$ is uncertain, but we will include a measure of expected price increases to control for any potential effect.

In the presale market, developers have lists of offer prices for their presale properties and they will remain the same for some time. If, during this period, the prices of completed flats increase significantly, the offer prices that previously appeared to be high become more attractive, since they may be lower than comparable completed units on the second-hand market. The changes in housing prices on the second-hand market will, therefore, affect PRE. To control for this change in market conditions during the presale period, we compared the second-hand housing price levels at each building's completion date $\left(\mathrm{T}_{\mathrm{OP}}\right)$ to those on the dates their developers decided to presell them $\left(\mathrm{T}_{\mathrm{DP}}\right)$. A higher ratio meant improved market conditions during the presale period and, thus, a higher PRE.

The data used in this study were drawn from projects developed from $1995^{11}$ to 2015 in Hong Kong provided by EPRC, Ltd., whose primary source of its data is the government's Land Registry. The sample covered 1103 private residential developments, over half of which were partly or entirely sold by presale. The project information was collected from the monthly reports issued by the Buildings Department and information on each developer came mainly from annual reports and the Lands Department. Last, the market-related information was obtained from the Rating and Valuation Department (RVD). We also used the Bloomberg Financial Database to obtain each developer's financial variables.

\footnotetext{
${ }^{10}$ It was calculated using a hedonic pricing model following Wong et al. (2012).

11 This was determined by data availability. Online property transaction records only started after 1990, meaning that if one included all the projects in the records, it is difficult to tell if a unit was presold during its early years. So, we only focused on developments that were completed on or after 1995 to minimize the possible mistakes that may come from overlooking the presale transactions.
} 
Table 3 shows the summary statistics: the full and sub-samples stratified by developers in Panel A and sub-samples stratified by the Consent/Non-consent Scheme in Panel B. According to Panel A, the average listed-developer flat had a considerably larger development scale and saleable floor area, but the building in which it was located was built on less expensive land. The scale of the development matched the financial strength of its developer(s). Such large plots of developable land are only available in Hong Kong's less-developed districts, which have lower land values. This

Table 3 Summary statistics

\begin{tabular}{|c|c|c|c|c|c|c|c|c|}
\hline \multicolumn{9}{|c|}{ Panel A: Entire sample } \\
\hline & \multicolumn{2}{|c|}{$\begin{array}{l}\text { Full sample } \\
\qquad(\text { obs. }=1103)\end{array}$} & \multicolumn{2}{|c|}{ Listed $($ obs. $=514)$} & \multicolumn{2}{|c|}{$\begin{array}{l}\text { Unlisted: Pre-match } \\
\quad(\text { obs. }=589)\end{array}$} & \multicolumn{2}{|c|}{$\begin{array}{l}\text { Unlisted: Post-match } \\
\quad(\text { obs. }=514)\end{array}$} \\
\hline & Mean & S.D. & Mean & S.D. & Mean & S.D. & Mean & S.D. \\
\hline PRE & 0.371 & 0.401 & 0.480 & 0.405 & 0.276 & 0.373 & 0.267 & 0.369 \\
\hline RIR & 0.020 & 0.050 & 0.024 & 0.050 & 0.015 & 0.050 & 0.020 & 0.051 \\
\hline VOL & 0.026 & 0.011 & 0.025 & 0.011 & 0.028 & 0.010 & 0.028 & 0.011 \\
\hline I94_98 & 0.271 & 0.445 & 0.093 & 0.291 & 0.425 & 0.495 & 0.341 & 0.474 \\
\hline $\mathrm{MSH}$ & 0.061 & 0.100 & 0.125 & 0.110 & 0.001 & 0.004 & 0.001 & 0.005 \\
\hline CONS & 0.499 & 0.500 & 0.695 & 0.461 & 0.329 & 0.470 & 0.358 & 0.480 \\
\hline SIZE & 307.4 & 509.867 & 559.7 & 636.581 & 87.65 & 173.120 & 89.74 & 175.187 \\
\hline ASFA & 946.3 & 965.913 & 969.7 & 937.227 & 926.0 & 990.572 & 967.2 & 1036.713 \\
\hline LVA & -0.124 & 0.365 & -0.144 & 0.360 & -0.106 & 0.368 & -0.071 & 0.368 \\
\hline BDP & 1.050 & 0.138 & 1.044 & 0.139 & 1.056 & 0.136 & 1.041 & 0.134 \\
\hline ADP & 1.021 & 0.146 & 1.021 & 0.137 & 1.021 & 0.154 & 1.035 & 0.148 \\
\hline \multicolumn{9}{|c|}{ Panel B: Listed company } \\
\hline & \multicolumn{2}{|c|}{$\begin{array}{l}\text { Listed } \\
\qquad(\text { obs. }=514)\end{array}$} & \multicolumn{2}{|c|}{$\begin{array}{l}\text { Listed \& NCONS } \\
\quad(\text { obs. }=157)\end{array}$} & \multicolumn{2}{|c|}{$\begin{array}{c}\text { Listed \& CONS: } \\
\text { Pre-match } \\
(\text { obs. }=357)\end{array}$} & \multicolumn{2}{|c|}{$\begin{array}{c}\text { Listed \& CONS: } \\
\text { Post-match } \\
(\text { obs. = 157) }\end{array}$} \\
\hline & Mean & S.D. & Mean & S.D. & Mean & S.D. & Mean & S.D. \\
\hline PRE & 0.480 & 0.405 & 0.484 & 0.404 & 0.478 & 0.407 & 0.383 & 0.399 \\
\hline RIR & 0.024 & 0.050 & 0.019 & 0.052 & 0.027 & 0.048 & 0.022 & 0.052 \\
\hline DER & 0.727 & 1.541 & 0.849 & 1.481 & 0.674 & 1.566 & 0.834 & 2.167 \\
\hline VOL & 0.025 & 0.011 & 0.024 & 0.011 & 0.025 & 0.011 & 0.024 & 0.012 \\
\hline I94_98 & 0.093 & 0.291 & 0.070 & 0.256 & 0.104 & 0.305 & 0.057 & 0.233 \\
\hline MSH & 0.125 & 0.110 & 0.104 & 0.109 & 0.134 & 0.110 & 0.118 & 0.112 \\
\hline PROR & -5.165 & 1.926 & -5.833 & 2.041 & -4.872 & 1.799 & -5.516 & 1.864 \\
\hline SIZE & 559.7 & 636.581 & 199.7 & 328.886 & 718 & 674.000 & 335.7 & 400.845 \\
\hline RCOM & 0.560 & 0.069 & 0.534 & 0.077 & 0.571 & 0.062 & 0.557 & 0.060 \\
\hline ASFA & 969.7 & 937.227 & 999.1 & 1246.238 & 956.7 & 764.623 & 1069.0 & 880.569 \\
\hline LVA & -0.144 & 0.360 & -0.080 & 0.318 & -0.243 & 0.332 & -0.038 & 0.342 \\
\hline BDP & 1.044 & 0.139 & 1.123 & 0.280 & 1.077 & 0.288 & 1.099 & 0.274 \\
\hline $\mathrm{ADP}$ & 1.021 & 0.137 & 1.048 & 0.165 & 1.01 & 0.121 & 1.026 & 0.091 \\
\hline
\end{tabular}

"Listed" means projects developed by listed developers; "Unlisted" means projects developed by private developers; "Listed \& NCONS" means listed developer projects under the Non-consent Scheme; "Listed \& CONS" means listed developer projects under the Consent Scheme 
leads to a much higher percentage of Consent Scheme projects developed by listed developers. The average market share in the listed-developer sample was $12.5 \%$ compared to a negligible $0.1 \%$ in the unlisted-developer sample. ${ }^{12}$

We further divided the listed developer sample into projects under the Consent and Non-consent Schemes and presented their summary statistics in Panel B. ${ }^{13}$ There were significant differences between the two Schemes. Most Non-consent Scheme projects were redevelopment projects and much smaller in scale than Consent Scheme projects due to difficulties in assembling units in multiple ownership buildings.

A comparison of the results of those estimates that used sub-samples may be affected by sample selection bias. Therefore, the data used to estimate Models 2, 3, 5 , and 6 were selected based on propensity scores estimated from probit models. The observations in each sub-sample were matched to the most similar observations in other sub-samples, so as to limit the influence from those observations that were dissimilar in the sub-samples. Specifically, the probit model (as specified in Eqs. (3) and (4)) was estimated to measure the probability that an unlisted-developer project was a listeddeveloper project and a (listed-developer) Consent Scheme project was a (listeddeveloper) Non-consent Scheme project, respectively.

$$
\begin{aligned}
\operatorname{Pr}\{L I S=1\} & =\Phi\left\{\gamma_{0}+\gamma_{1} \text { RIR }+\gamma_{2} V O L+\gamma_{3} I 94 \_98+\gamma_{4} M S H+\gamma_{5} C O N S\right. \\
& \left.+\gamma_{6} S I Z E+\gamma_{7} A S F A+\gamma_{8} L V A+\gamma_{9} B D P+\gamma_{10} A D P\right\}
\end{aligned}
$$

We treated the listed-developer group as the treatment group compared to the unlisted-developer group. The first binary dependent variable was $L I S$, which equaled 1 if the project was developed by a listed developer and 0 if by an unlisted developer. The independent variables were the same as those in Eq. (1).

$$
\begin{aligned}
\operatorname{Pr}\{N C O N S=1\} & =\Phi\left\{\alpha_{0}+\alpha_{1} R I R+\alpha_{2} V O L+\alpha_{3} I 94 \_98+\alpha_{4} M S H+\alpha_{5} S I Z E\right. \\
& +\alpha_{6} S C O M+\alpha_{7} A S F A+\alpha_{8} L V A+\alpha_{9} B D P+\alpha_{10} A D P+\alpha_{11} D E R \\
& \left.+\alpha_{12} P R O R\right\}
\end{aligned}
$$

The second binary dependent variable was NCONS, which assumed a value of 1 if the development was under the Non-consent Scheme and 0 if under the Consent Scheme. This was determined because there were fewer observations of Non-consent Scheme projects than Consent Scheme projects in the listed-developer sample. The independent variables included everything shown except for CONS in Eq. (4).

The results of the two probit estimations are shown in Table 4. Panel A shows that listed-developer projects are significantly more likely to be developed on less expensive land under the Consent Scheme by companies with higher market shares. In Panel B,

\footnotetext{
${ }^{12} \mathrm{MSH}$ for unlisted developers might have been underestimated. This was because developer information was not available for all projects in Hong Kong. The small parts of projects without developer information were assumed to be developed by unlisted smaller developers with very low market shares.

${ }^{13}$ We did not compare the Consent and Non-consent Scheme projects within the full sample because they tried to include DER and PROR, which were unavailable in the full sample. A complete consideration of the variables limited our sample to listed-developer projects.
} 
Table 4 Results of the probit models

\begin{tabular}{|c|c|c|c|}
\hline Variable & Coefficient & (Wald $X^{2}$ ) & Marginal effect \\
\hline \multicolumn{4}{|c|}{ Panel A: Probit for listed developer projects (LIS) } \\
\hline Constant & -1.800 & $(0.15)$ & - \\
\hline RIR & -5.086 & $(0.15)$ & -0.465 \\
\hline VOL & -6.599 & $(0.45)$ & -0.603 \\
\hline I94_98 & $-1.038^{\mathrm{a}}$ & $(17.8)$ & -0.095 \\
\hline MSH & $191.7^{\mathrm{a}}$ & $(74.5)$ & 17.52 \\
\hline CONS & $0.392^{\mathrm{b}}$ & $(5.8)$ & 0.036 \\
\hline SIZE & $3.1 \mathrm{E}-04$ & $(0.8)$ & $2.8 \mathrm{E}-05$ \\
\hline ASFA & $5.4 \mathrm{E}-05$ & $(0.63)$ & $5.0 \mathrm{E}-06$ \\
\hline LVA & $0.528^{\mathrm{b}}$ & $(6.2)$ & 0.048 \\
\hline BDP & -0.110 & $(0.01)$ & -0.010 \\
\hline $\mathrm{ADP}$ & $0.784^{\mathrm{c}}$ & $(3.0)$ & 0.072 \\
\hline \multicolumn{4}{|c|}{ Panel B: Probit for non-consent scheme projects (NCONS) } \\
\hline Constant & -0.173 & $(0.01)$ & - \\
\hline RIR & -0.825 & $(0.06)$ & -0.212 \\
\hline DER & 0.067 & $(2.1)$ & 0.017 \\
\hline VOL & 8.080 & $(1.2)$ & 2.072 \\
\hline I94_98 & 0.065 & $(0.06)$ & 0.017 \\
\hline MSH & -0.052 & $(0.01)$ & -0.013 \\
\hline PROR & $-0.113^{\mathrm{b}}$ & $(4.1)$ & -0.029 \\
\hline SIZE & $-9.0 \mathrm{E}-04^{\mathrm{a}}$ & $(17.5)$ & $-2.3 \mathrm{E}-04$ \\
\hline $\mathrm{RCOM}$ & $-2.412^{\mathrm{b}}$ & $(5.2)$ & -0.062 \\
\hline ASFA & $-3.0 \mathrm{E}-04^{\mathrm{a}}$ & (12.0) & $-7.8 \mathrm{E}-05$ \\
\hline LVA & $1.394^{\mathrm{a}}$ & $(42.2)$ & 0.358 \\
\hline $\mathrm{BDP}$ & 0.064 & $(0.95)$ & 0.016 \\
\hline ADP & 0.447 & $(0.92)$ & 0.014 \\
\hline
\end{tabular}

$\mathrm{a}, \mathrm{b}$, and $\mathrm{c}$ denote the significance of the estimated coefficient based on the Wald $\mathrm{X}^{2}$ test statistic at the $1 \%$, $5 \%$, and $10 \%$ levels, respectively

Non-consent Scheme projects are significantly more likely to be developed by companies with lower market shares on more valuable land. Their development scales, communal facilities, and flat sizes are smaller than those under the Consent Scheme. Propensity scores are calculated based on the probit results. These scores are then used to match each listed-developer project to the nearest unlisted-developer project, and each (listed-developer) Non-consent Scheme project to the nearest (listed-developer) Consent Scheme project. The matching procedure is performed with replacement. After matching, there should be an equal number of listed-developer and unlisted-developer projects (a total of 1028 observations) and an equal number of even observations (in total 314 observations) of Consent Scheme and Non-consent Scheme projects in the listed-developer sample. The summary statistics of the propensity-score matched samples are presented on the last column of Table 3. 


\section{Results}

Table 5 presents the central results of this study. Panel A shows the results of estimating Models 1, 2, and 3 using all and only the matched samples. The results of both the preand post-marching data were very similar, although the estimated coefficients for the post-matching data were slightly less significant than those for the pre-matching data. In Models 1 and 3, the coefficients of RIR were positively correlated with PRE, whilst the correlation became insignificant in Model 2 (listed companies). The post-match columns showed the results with the matched pairs. The last column showed the difference in the coefficients between listed and unlisted companies after matching. We found a significantly lower coefficient of RIR for listed developers, while other variables remained almost the same except for MSH, SIZE, and ASFA, which might have been caused by their mean value differences even after matching. The results of Model 2 rejected $\mathrm{H} 1$ for listed companies, but not for those of unlisted companies. This difference was reasonable in the case of Hong Kong, whose major developers are very large in size with strong balance sheets and big coffers (Renaud et al. 1997). They enjoy lower finance costs compared to smaller developers. We failed to consistently obtain a positive DER for the listed companies in Model 4, as shown in Panel B.

The coefficients of the expected volatility variables (VOL and I94_98) were positive. These results strongly supported hedging against expected future price volatility and gave developers an incentive to presell, which was consistent with H2. In the listed developer sample, for example, one standard deviation increase in price volatility led to an increase of $4.2 \%$ during a presale. The coefficient of $M S H$ was positive and significantly larger for unlisted than for listed developers. This might have been due to the lower $M S H$ value for such developers. This result was consistent with the prediction of $\mathrm{H} 3$.

The positive and significant coefficients of PROR and SIZE (Model 4) in Panel B suggested that developers had stronger incentives to presell units in their larger projects relative to the size of their companies, which agreed with $\mathrm{H} 4$. A one-unit increase in project risk led to a $4.7 \%$ increase in presales. $\mathrm{H} 5$ predicted that a developer's incentive to presell was higher for Non-consent Scheme than for Consent Scheme projects. The negative and significant coefficient of CONS was consistent with this prediction. Moreover, the coefficients in Model 6 (Non-consent Scheme) were generally larger in magnitude and more significant than those in Model 5 (Consent Scheme) in both the pre-match and post-match samples. This was true for the coefficients of VOL, which confirmed H6. Finally, the insignificant coefficient of RCOM rejected H7. These results suggested that information asymmetry on property quality may not be an important consideration for buyers who opt for presales.

The results were robust across the different assumptions on the timing of the decisions for spot sales (i.e., to not presell) along with U.S. and Hong Kong interest rates.

\section{Conclusion}

This study investigated what motivated developers to presell. We proposed that the standard neoclassical economic analysis could not answer this question. Information 


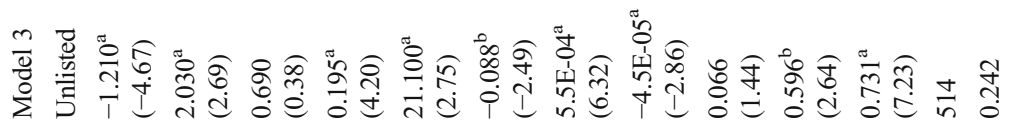

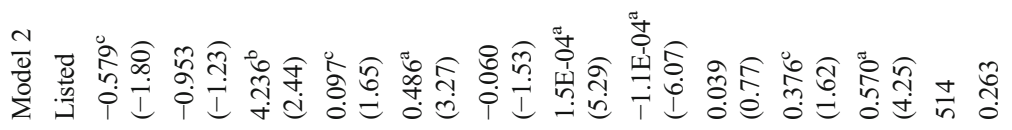

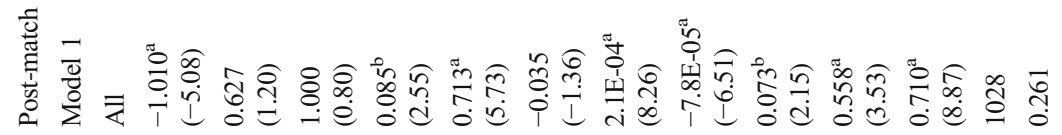

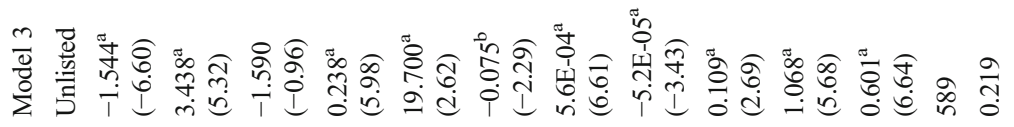

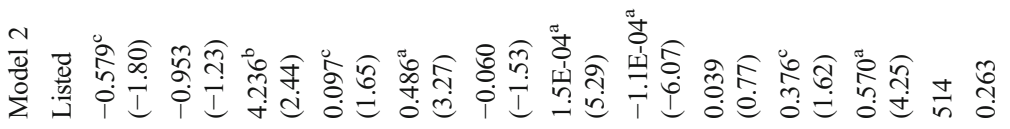

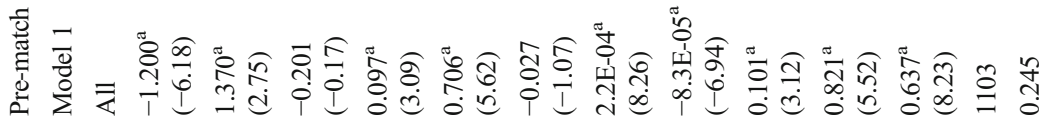

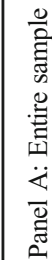

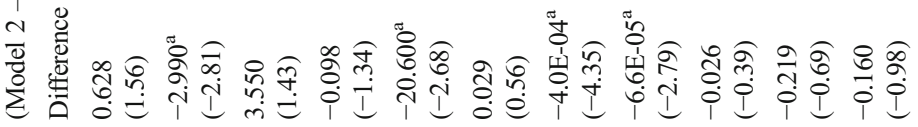



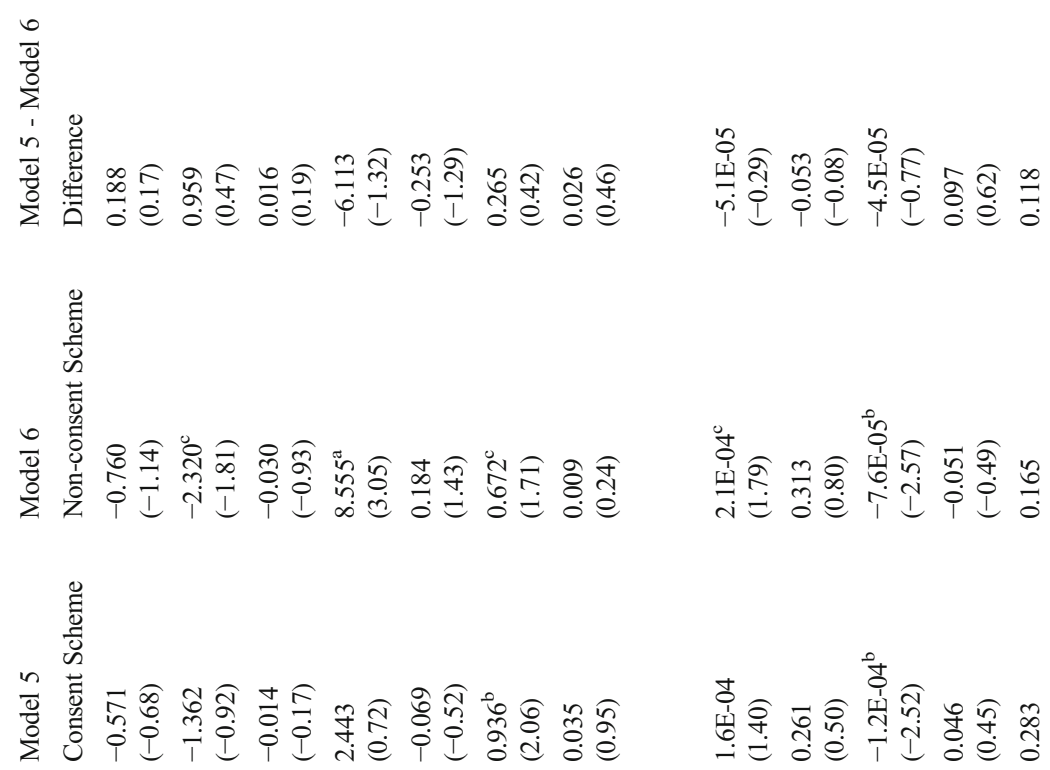

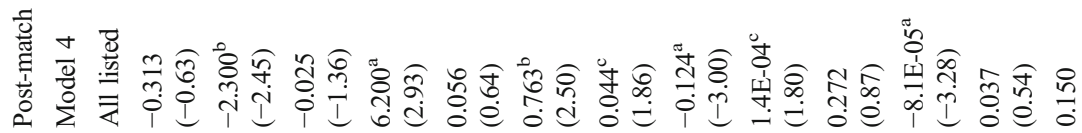

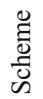

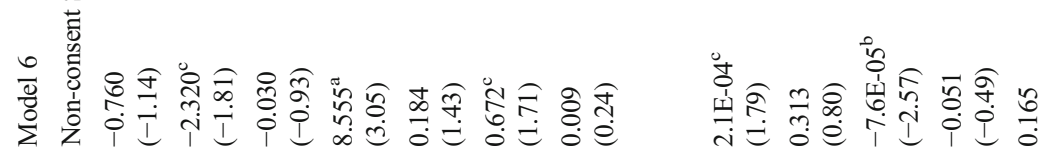

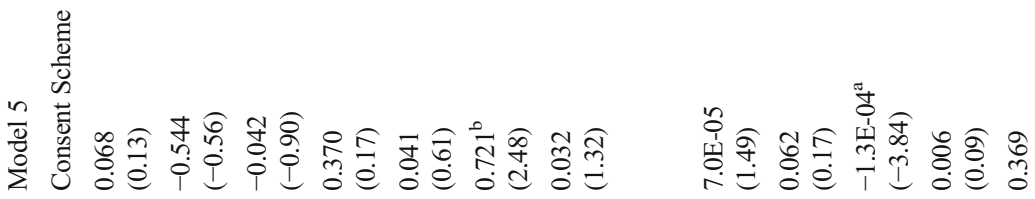

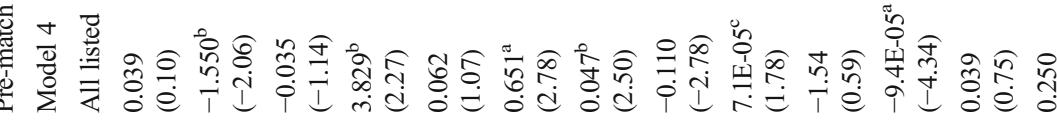

过

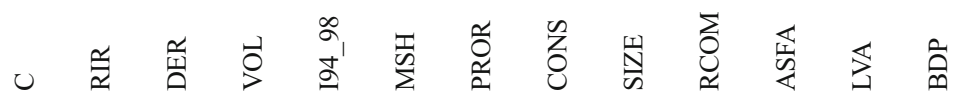




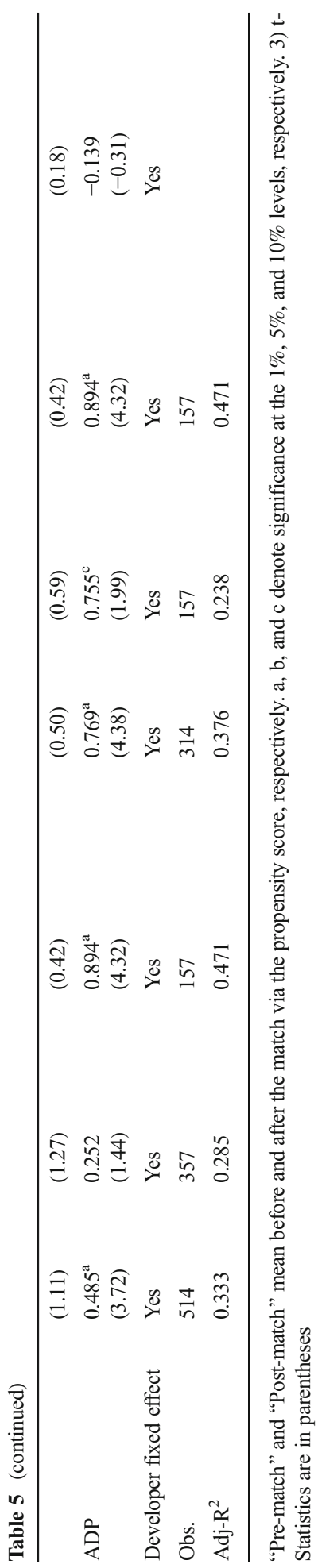

\section{型 Springer}


asymmetry, risk aversion, regulatory and policy changes, and project finance sources were also important factors for explaining developers' propensity to presell. Our empirical results for Hong Kong suggested that developers used presales to hedge against future price fluctuations. When presale flexibility was deterred by policies or regulations, developers' motivation to presell declined. There was also empirical evidence to suggest that developers were more likely to use presales when specific project risks were high. However, presales as an alternative source of finance were only important for smaller developers.

These findings should make the government rethink its presale regulations. Restricting presales may weaken the ability of developers, particularly those with larger market shares, to deal with property price volatility. Smaller developers may suffer financial problems, since they rely on presales to partly finance their projects.

Acknowledgements We appreciate the helpful comments from Prof. Hongyu Liu, Prof. Ong Seow Eng, Dr. Zan Yang, and other participants in the 2016 Asia Pacific Real Estate Research Symposium, as well as the discussion given by Dr. Ka Yui Leung at the 2017 AREUEA-ASSA Conference and Mr. Haotong Li at the 2016 AREUEA International Conference. All errors are ours.

Open Access This article is distributed under the terms of the Creative Commons Attribution 4.0 International License (http://creativecommons.org/licenses/by/4.0/), which permits unrestricted use, distribution, and reproduction in any medium, provided you give appropriate credit to the original author(s) and the source, provide a link to the Creative Commons license, and indicate if changes were made.

\section{References}

Chan, S. H., Fang, F., \& Yang, J. (2008). Presales, financing constraints, and developers' production decisions. Journal of Real Estate Research, 30(3), 2008.

Chang, C. O., \& Ward, C. W. (1993). Forward pricing and the housing market: the pre-sales housing system in Taiwan. Journal of Property Research, 10(3), 217-227.

Chau, K. W., \& Choy, L. H. (2011). Let the buyer or seller beware: measuring lemons in the housing market under different doctrines of law governing transactions and information. Journal of Law and Economics, 54(S4), S347-S365.

Chau, K. W., Wong, S. K., \& Yiu, C. Y. (2003). Price discovery function of forward contracts in the real estate market: an empirical test. Journal of Financial Management of Property and Construction, 8(3), 129137.

Chau, K. W., Wong, S. K., \& Yiu, C. Y. (2007). Housing quality in the presale contracts market. Journal of Real Estate Finance and Economics, 34(3), 313-325.

Cunningham, C. R. (2006). House price uncertainty, timing of development, and vacant land prices: evidence for real options in Seattle. Journal of Urban Economics, 59(1), 1-31.

Deng, Y., \& Liu, P. (2009). Mortgage prepayment and default behavior with embedded presale contract risks in China's housing market. Journal of Real Estate Finance and Economics, 38(3), 2009.

Edelstein, R., Liu, P., \& Wu, F. (2012). The market for real estate presales: a theoretical approach. Journal of Real Estate Finance and Economics, 45(1), 30-48.

Fan, G. Z., Pu, M., \& Ong, S. E. (2012). Optimal portfolio choices, house risk hedging and the pricing of forward house transactions. Journal of Real Estate Finance and Economics, 45(1), 3-29.

Hwang, M., \& Quigley, J. M. (2010). Housing price dynamics in time and space: predictability, liquidity and investor returns. Journal of Real Estate Finance and Economics, 41(1), 3-23.

Lai, R. N., Wang, K., \& Zhou, Y. (2004). Sale before completion of development: pricing and strategy. Real Estate Economics, 32, 329-357.

Lands Department, Hong Kong (1999). Lands department consent scheme for sale of units in uncompleted private residential developments. Legal Advisory Conveyancing Office Circular Memorandum No. 40A. Hong Kong. 
Leung, B. Y., Hui, E. C., \& Seabrooke, B. (2007a). Asymmetric information in the Hong Kong forward property market. International Journal of Strategic Property Management, 11(2), 91-106.

Leung, B. Y., Hui, E., \& Seabrooke, B. (2007b). Risk transfer of presale properties and the construction of a forward property price index. Pacific Rim Property Research Journal, 13(2), 194-212.

Li, L., \& Chau, K.W. (2017). Measuring price differentials between large and small housing units: The case of Hong Kong. In Proceedings of the 20th International Symposium on Advancement of Construction Management and Real Estate (pp. 663-675). Singapore: Springer.

Ong, S. E. (1997). Building defects, defect warranty and disincentive effects of precompletion marketing. Journal of Property Finance, 8(1), 35-50.

Ong, S. E. (1999). Aborted property transactions: seller under-compensation in the absence of legal recourse. Journal of Property Investment \& Finance, 17(2), 126-144.

Renaud, B., Pretorius, F., \& Pasadilla, B. (1997). Markets at work: Dynamics of the residential real estate market in Hong Kong (Vol. 1). Hong Kong University Press.

Wang, K., \& Zhou, Y. (2006). Equilibrium real options exercise strategies with multiple players: the case of real estate markets. Real Estate Economics, 34(1), 1-49.

Wang, K., Zhou, Y., Chan, S., \& Chau, K. W. (2000). Over-confidence and cycles in real estate markets: cases in Hong Kong and Asia. International Real Estate Review, 3(1), 93-108.

Wong, S. K., Yiu, C. Y., Tse, M. K. S., \& Chau, K. W. (2006). Do the forward sales of real estate stabilize spot prices? Journal of Real Estate Finance and Economics, 32(3), 289-304.

Wong, S. K., Chau, K. W., \& Yiu, C. Y. (2007). Volatility transmission in the real estate spot and forward markets. Journal of Real Estate Finance and Economics, 35(3), 281-293.

Wong, S. K., Yiu, C. Y., \& Chau, K. W. (2012). Liquidity and information asymmetry in the real estate market. Journal of Real Estate Finance and Economics, 45(1), 49-62.

Yao, H., \& Pretorius, F. (2014). Demand uncertainty, development timing and leasehold land valuation: empirical testing of real options in residential real estate development. Real Estate Economics, 42(4), $829-868$. 